\title{
MOLECULAR DYNAMICS STUDY OF INSULIN MUTANTS
}

\author{
(D) Olga Zhytniakivska*, (DUliana Tarabara, (DValeriya Trusova, \\ (D) Kateryna Vus, (D) Galyna Gorbenko \\ Department of Medical Physics and Biomedical Nanotechnologies, V.N. Karazin Kharkiv National University \\ 4 Svobody Sq., Kharkiv, 61022, Ukraine \\ *Corresponding Author: olya_zhitniakivska@yahoo.com \\ Received April 1, 2021; revised April 22, 2021; accepted April 23, 2021
}

Human insulin, a small protein hormone consisting of A-chain (21 residues) and B-chain ( 30 residues) linked by three disulfide bonds, is crucial for controlling the hyperglycemia in type I diabetes. In the present work molecular dynamics simulation (MD) with human insulin and its mutants was used to assess the influence of 10 point mutations $\left(\mathrm{His}^{\mathrm{A} 8}, \mathrm{Val}^{\mathrm{A} 10}, \mathrm{Asp}^{\mathrm{B} 10}, \mathrm{Gln}^{\mathrm{B} 17}, \mathrm{Ala}^{\mathrm{B} 17}, \mathrm{Gln}^{\mathrm{B} 18}, \mathrm{Asp}^{\mathrm{B} 25}, \mathrm{Thr}^{\mathrm{B} 26}, \mathrm{Glu}^{\mathrm{B} 27}\right.$, $\left.\mathrm{Asp}^{\mathrm{B} 28}\right), 6$ double mutations $\left(\mathrm{Glu}^{\mathrm{A} 13}+\mathrm{Glu}^{\mathrm{B} 10}, \mathrm{Ser}^{\mathrm{A} 13}+\mathrm{Glu}^{\mathrm{B} 27}, \mathrm{Glu}^{\mathrm{B} 1}+\mathrm{Glu}^{\mathrm{B} 27}, \mathrm{Ser}^{\mathrm{B} 2}+\mathrm{Asp}^{\mathrm{B} 10}, \mathrm{Asp}^{\mathrm{B} 9}+\mathrm{Glu}^{\mathrm{B} 27}, \mathrm{Glu}^{\mathrm{B} 16}+\mathrm{Glu}^{\mathrm{B} 27}\right)$ and one triple mutation $\left(\mathrm{Glu}^{\mathrm{A} 15}+\mathrm{Asp}^{\mathrm{A} 18}+\mathrm{Asp}^{\mathrm{B} 3}\right)$ in the protein sequence on the structure and dynamics of human insulin. A series of thermal unfolding MD simulations with wild type (WT) human insulin and its mutants was performed at $400 \mathrm{~K}$ with GROMACS software (version 5.1) using the CHARMM36m force field. The MD results have been analyzed in terms of the parameters characterizing both the global and local protein structure, such as the backbone root mean-square deviation, gyration radius, solvent accessible surface area, the root meansquare fluctuations and the secondary structure content. The MD simulation data showed that depending on time evolution of integral characteristics, the examined mutants can be tentatively divided into three groups: 1) the mutants $\mathrm{His}^{\mathrm{A} 8}, \mathrm{Val}^{\mathrm{A} 10}, \mathrm{Ala}^{\mathrm{B} 17}, \mathrm{Asp}^{\mathrm{B} 25}, \mathrm{Thr}^{\mathrm{B} 26}$, $\mathrm{Glu}^{\mathrm{B} 27}, \mathrm{Glu}^{\mathrm{A} 13}+\mathrm{Glu}^{\mathrm{B} 10}, \mathrm{Glu}^{\mathrm{B} 1}+\mathrm{Glu}^{\mathrm{B} 27}$ and $\mathrm{Glu}^{\mathrm{B} 16}+\mathrm{Glu}^{\mathrm{B} 27}$, which exert stabilizing effect on the protein structure in comparison with wild type insulin; 2) the mutants $\mathrm{Gln}^{\mathrm{B} 17}, \mathrm{Asp}^{\mathrm{B} 10}, \mathrm{Ser}^{\mathrm{B} 2}+\mathrm{Asp}^{\mathrm{B} 10}$ and $\mathrm{Glu}^{\mathrm{A} 15}+\mathrm{Asp}^{\mathrm{A} 18}+\mathrm{Asp}^{\mathrm{B} 3}$ that did not significantly affect the dynamical properties of human insulin with a minimal stabilizing impact; 3) the mutants $\mathrm{Asp}^{\mathrm{B} 28}$, Asp ${ }^{\mathrm{B} 9}+\mathrm{Glu}^{\mathrm{B} 27}$ and $\mathrm{Ser}^{\mathrm{A} 13}+\mathrm{Glu}^{\mathrm{B} 27}$, Gln ${ }^{\mathrm{B} 18}$, destabilizing the protein structure. Analysis of the secondary structure content provided evidence for the influence of $\mathrm{Asp}^{\mathrm{B} 28}, \mathrm{Asp}^{\mathrm{B} 9}+\mathrm{Glu}^{\mathrm{B} 27}$ and $\mathrm{Ser}^{\mathrm{A} 13}+\mathrm{Glu}^{\mathrm{B} 27}, \mathrm{Gln}^{\mathrm{B} 18}$ on the insulin unfolding. Our MD results indicate that the replacement of superficial nonpolar residues in the insulin structure by hydrophilic ones gives rise to the increase in protein stability in comparison with the wild type protein.

KEYWORDS: human insulin, mutants, molecular dynamics simulation, amyloid.

Human insulin, a small protein hormone consisting of an acidic A-chain (21 residues) and a basic B-chain (30 residues) linked by three disulfide bonds, is crucial for controlling the hyperglycemia in type I diabetes [1-3]. However, medical and pharmaceutical applications of this hormone are complicated by its predisposition for aggregation and formation of amyloid fibrils [4-8]. Specifically, it was shown that insulin is capable of forming the amyloid fibrils at the sites of the repeated insulin injection during the therapy of patients with diabetes, thereby inducing the localized insulin-derived amyloidosis (insulin amyloidoma) [4,5]. Moreover, the tendency of insulin to form amyloid fibrils under stressful conditions (elevated temperature, agitation, $\mathrm{pH}$, etc.) represents a serious obstacle during industrial purification, storage and drug delivery of protein-based pharmaceuticals [6,7]. Despite extensive research efforts, the exact molecular details of the insulin amyloid transformation are still under debate. The insulin fibril formation in vitro is usually described by the classical nucleation-dependent polymerization model $[1,8,9]$. However, many other mechanisms for insulin fibrillization have been proposed including the heterogeneous nucleation [10], colloidal coagulation model $[9,11]$ and downhill polymerization $[9,11,12]$.

The in vitro oligomerization and aggregation of insulin is essentially controlled by environmental conditions such as $\mathrm{pH}[13,14]$, ionic strength $[15,16]$, temperature $[14,17,18]$, the presence of ions $[19,20]$, and protein concentration $[14,21]$. Previous studies suggested that the early stages of insulin fibrillation are governed mainly by hydrophobic interactions [22,23]. However, several lines of evidence pointed out the importance of the electrostatic interactions in the insulin fibrillization at the initial stage of nucleation $[9,23,24]$. It is believed that the flexible B-chain of insulin is more important for the protein transition into amyloid state than the rest of molecule [14,23, 25-27]. However, using screening of the amyloid-forming insulin sequence Eisenberg's team suggested at least two protein segments responsible for the insulin amyloid conversion: the $\mathrm{L}^{\mathrm{B} 11}$ VEALYL ${ }^{\mathrm{B} 17}$ segment of the B-chain accounting for the formation of fibril spine and the $\mathrm{S}^{\mathrm{A} 12} \mathrm{LYQLENY}{ }^{\mathrm{A} 19}$ segment from the A-chain stabilizing the fibril structure [27]. Furthermore, it was showed that the disordered N-terminal segments of both A-and B-chains along with the residues $\mathrm{Leu}^{\mathrm{B} 15}$, $\mathrm{Phe}^{\mathrm{B} 24}$ and $\mathrm{Tyr}^{\mathrm{A} 19}$ may also contribute to fibril formation [28]. In addition, the surfaces consisting of $\mathrm{His}^{\mathrm{B} 10}$, $\mathrm{Leu}^{\mathrm{B} 17}, \mathrm{Tyr}^{\mathrm{B} 16}, \mathrm{Phe}^{\mathrm{B} 25}$ and $\mathrm{Thr}^{\mathrm{A} 8}$ were assumed as the potential sites that trigger insulin fibrillization [14,28]. Notably, both A- and B-chains of insulin by their own are capable of forming the amyloid fibrils under denaturing conditions [24]. Intriguingly, the mutations in the C-terminus of human insulin B-chain were reported to affect the amyloidogenic propensity of the protein [14,29-31]. Specifically, the removal of five residues from the B-chain led to the enhancement of insulin fibrillization [14], while the mutants T30R and K29R/T30R showed different resistance against stress-induced fibril growth on the initial stage of nucleation [23]. Furthermore, the delay in the lag phase of insulin fibrillization was observed for the point mutations H10D and L17Q [31], whereas the substitution of Pro $^{\mathrm{B} 28}$ with (4S)-hydroxyproline (Hzp) resulted in the higher resistance to fibril formation [32]. 
The aim of the present study was to assess the influence 10 point mutations (His ${ }^{\mathrm{A} 8}, \mathrm{Val}^{\mathrm{A} 10}, \mathrm{Asp}^{\mathrm{B} 10}, \mathrm{Gln}^{\mathrm{B} 17}, \mathrm{Ala}^{\mathrm{B} 17}$, $\left.\mathrm{Gln}^{\mathrm{B} 18}, \mathrm{Asp}^{\mathrm{B} 25}, \mathrm{Thr}^{\mathrm{B} 26}, \mathrm{Glu}^{\mathrm{B} 27}, \mathrm{Asp}^{\mathrm{B} 28}\right), 6$ double mutations $\left(\mathrm{Glu}^{\mathrm{A} 13}+\mathrm{Glu}^{\mathrm{B} 10}, \mathrm{Ser}^{\mathrm{A} 13}+\mathrm{Glu}^{\mathrm{B} 27}, \mathrm{Glu}^{\mathrm{B} 1}+\mathrm{Glu}^{\mathrm{B} 27}, \mathrm{Ser}^{\mathrm{B} 2}+\mathrm{Asp}^{\mathrm{B} 10}\right.$, $\left.\mathrm{Asp}^{\mathrm{B} 9}+\mathrm{Glu}^{\mathrm{B} 27}, \mathrm{Glu}^{\mathrm{B} 16}+\mathrm{Glu}^{\mathrm{B} 27}\right)$ and one triple mutation $\left(\mathrm{Glu}^{\mathrm{A} 15}+\mathrm{Asp}^{\mathrm{A} 18}+\mathrm{Asp}^{\mathrm{B} 3}\right)$ in the human insulin sequence on the protein structure and dynamics. To this end, a series of thermal unfolding MD simulations with wild type (WT) protein and its mutants was performed.

\section{MOLECULAR DYNAMICS SIMULATIONS}

The molecular dynamics simulations were conducted with GROMACS software (version 5.1) using the CHARMM36m force field with TIP3P water model [33]. The starting structure for simulations was taken from the Protein Data Bank (PDB entry for human insulin 3I3Z). The mutations $\mathrm{His}^{\mathrm{A} 8}, \mathrm{Val}^{\mathrm{A} 10}, \mathrm{Asp}^{\mathrm{B} 10}, \mathrm{Gln}^{\mathrm{B} 17}, \mathrm{Ala}^{\mathrm{B} 17}, \mathrm{Gln}^{\mathrm{B} 18}, \mathrm{Asp}^{\mathrm{B} 25}$, $\mathrm{Thr}^{\mathrm{B} 26}, \mathrm{Glu}^{\mathrm{B} 27}, \mathrm{Asp}^{\mathrm{B} 28}, \mathrm{Glu}^{\mathrm{A} 13}+\mathrm{Glu}^{\mathrm{B} 10}, \mathrm{Ser}^{\mathrm{A} 13}+\mathrm{Glu}^{\mathrm{B} 27}, \mathrm{Glu}^{\mathrm{B} 1}+\mathrm{Glu}^{\mathrm{B} 27}, \mathrm{Ser}^{\mathrm{B} 2}+\mathrm{Asp}^{\mathrm{B} 10}, \mathrm{Asp}^{\mathrm{B} 9}+\mathrm{Glu}^{\mathrm{B} 27}, \mathrm{Glu}^{\mathrm{B} 16}+\mathrm{Glu}^{\mathrm{B} 27}$, $\mathrm{Glu}^{\mathrm{A} 15}+\mathrm{Asp}^{\mathrm{A} 18}+\mathrm{Asp}^{\mathrm{B} 3}$ were introduced to the protein sequence using the web-based graphical interface CHARMM-GUI. The input files for MD calculations were prepared using the CHARMM-GUI Quick MD simulator [34].

The human insulin and its mutants were solvated in the rectangular box fitted to protein size. The minimal distance from the protein molecule to the box edges was $10 \AA$. To obtain a neutral total charge of the system the required amount of positive ions was added. The number of atoms in the solvated protein systems varied from 14670 to 17573 . The Particle Mesh Ewald algorithm was used to treat the long-range electrostatic interactions [35]. The minimization and equilibration of the system were performed during $100 \mathrm{ps}$ and $500 \mathrm{ps}$, respectively. The time step for MD simulations was 2 fs. The trajectories and coordinates were saved every 2 ps for further analysis. The whole time interval for MD calculations was $100 \mathrm{~ns}$. The MD simulations of the human insulin and its mutants were performed at $400 \mathrm{~K}$ and a pressure 1 bar. The analysis tools provided by GROMACS were used to calculate the root mean-square deviations (RMSD), root mean-square fluctuations of the C-alpha atoms (RMSF), radius of gyration (Rg) and solvent-accessible surface area (SASA) per residue. The evolution of the secondary structure was followed using the VMD Timeline tool [36] and Tcl scripts.

\section{RESULTS AND DISCUSSION}

To examine the changes in the conformational behaviour of the mutated human insulin as compared to its wild type counterpart we analysed the thermal unfolding trajectories by calculating the parameters reflecting the changes in both the global and local protein structure (RMSD, Rg, SASA, RMSF) and the secondary structure content. Fig. 1 shows the changes of the backbone root mean square deviations with time.
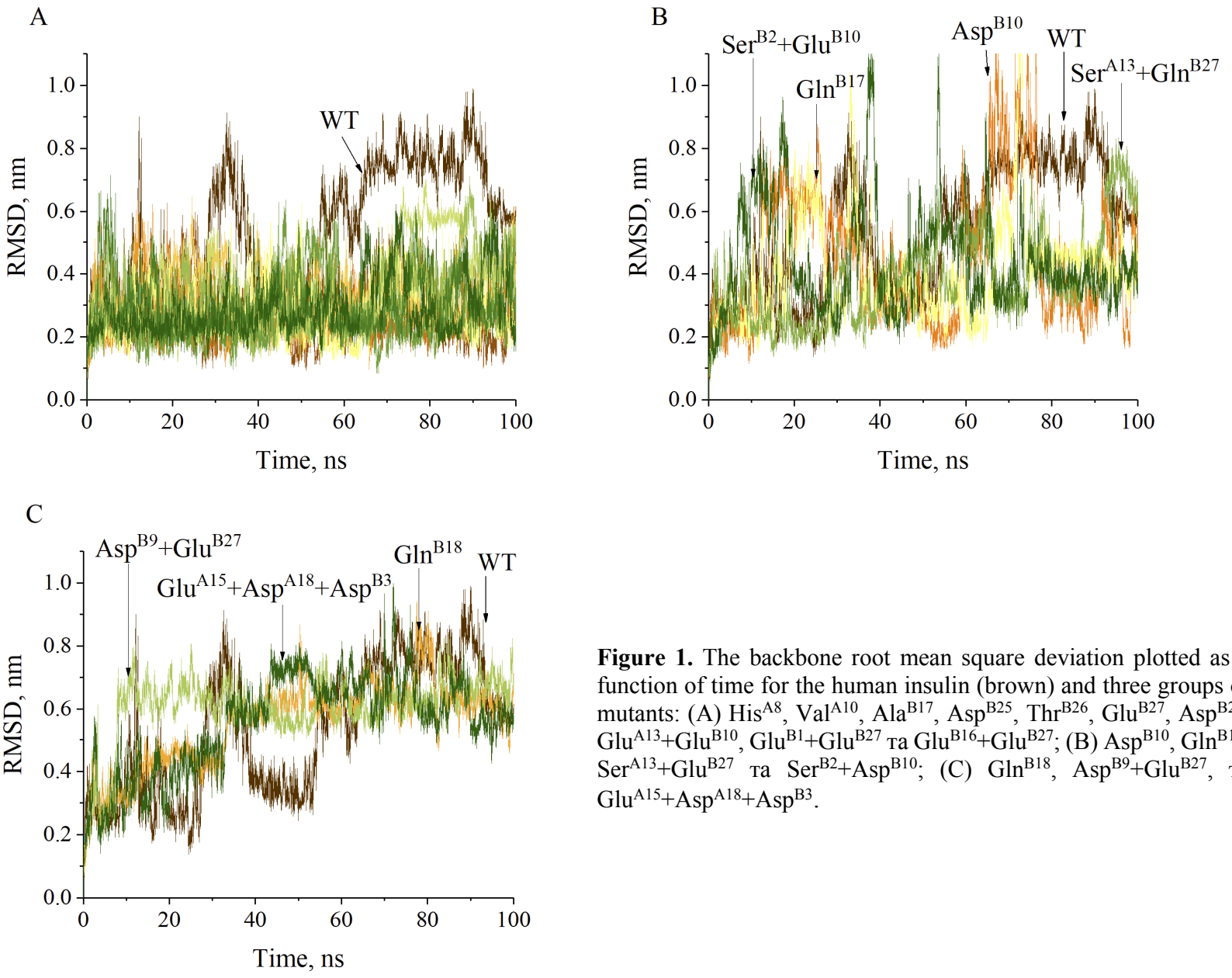

Figure 1. The backbone root mean square deviation plotted as a function of time for the human insulin (brown) and three groups of mutants: (A) $\mathrm{His}^{\mathrm{A} 8}, \mathrm{Val}^{\mathrm{A} 10}, \mathrm{Ala}^{\mathrm{B} 17}, \mathrm{Asp}^{\mathrm{B} 25}, \mathrm{Thr}^{\mathrm{B} 26}, \mathrm{Glu}^{\mathrm{B} 27}, \mathrm{Asp}^{\mathrm{B} 28}$, $\mathrm{Glu}^{\mathrm{A} 13}+\mathrm{Glu}^{\mathrm{B} 10}, \mathrm{Glu}^{\mathrm{B} 1}+\mathrm{Glu}^{\mathrm{B} 27} \mathrm{Ta} \mathrm{Glu}^{\mathrm{B} 16}+\mathrm{Glu}^{\mathrm{B} 27}$; (B) $\mathrm{Asp}^{\mathrm{B} 10}, \mathrm{Gln}^{\mathrm{B} 17}$, $\mathrm{Ser}^{\mathrm{A} 13}+\mathrm{Glu}^{\mathrm{B} 27}$ та $\mathrm{Ser}^{\mathrm{B} 2}+\mathrm{Asp}^{\mathrm{B} 10}$; (C) $\mathrm{Gln}^{\mathrm{B} 18} \mathrm{Asp}^{\mathrm{B} 9}+\mathrm{Glu}^{\mathrm{B} 27}$, та $\mathrm{Glu}^{\mathrm{A} 15}+\mathrm{Asp}^{\mathrm{A} 18}+\mathrm{Asp}^{\mathrm{B} 3}$. 
As seen in Fig. 2, the calculated RMSD values for human insulin and its mutants do not exceed 1 nm, except shorttime fluctuations of $\mathrm{Asp}^{\mathrm{B} 10}, \mathrm{Gln}^{\mathrm{B} 17}$ and $\mathrm{Ser}^{\mathrm{B} 2}+\mathrm{Asp}^{\mathrm{B} 10}$ Notably, for the WT insulin the time dependence of RMSD is characterized by four periods: 1) strong fluctuations $\sim 0.3 \mathrm{~nm}$ with deviations up to $0.9 \mathrm{~nm}$ during the first $25 \mathrm{~ns}$ of simulation; 2) a slight increase of RMSD values to $0.66-0.78 \mathrm{~nm}$ during the next $3 \mathrm{~ns}$ followed by the fluctuations at this level during $\sim 8 \mathrm{~ns}$; 3) substantial decrease of RMSD values to 0.33-0.38 nm starting from $\sim 36 \mathrm{~ns}$; 4) gradual RMSD increase to $0.6-0.8 \mathrm{~nm}$ remaining almost stable during the last $50 \mathrm{~ns}$ of the simulation. The RMSDs of mutants His ${ }^{\mathrm{A} 8}$, $\mathrm{Val}^{\mathrm{A} 10}, \mathrm{Ala}^{\mathrm{B} 17}, \mathrm{Asp}^{\mathrm{B} 25}, \mathrm{Thr}^{\mathrm{B} 26}, \mathrm{Glu}^{\mathrm{B} 27}, \mathrm{Asp}^{\mathrm{B} 28}, \mathrm{Glu}^{\mathrm{A} 13}+\mathrm{Glu}^{\mathrm{B} 10}, \mathrm{Glu}^{\mathrm{B} 1}+\mathrm{Glu}^{\mathrm{B} 27}$ and $\mathrm{Glu}^{\mathrm{B} 16}+\mathrm{Glu}^{\mathrm{B} 27}$ were significantly lower during the simulation time compared with the WT insulin. As seen in Fig. 2, the mutants $\mathrm{Gln}^{\mathrm{B} 18}$, Asp $^{\mathrm{B} 9}+\mathrm{Glu}^{\mathrm{B} 27}$ and $\mathrm{Glu}^{\mathrm{A} 15}+\mathrm{Asp}^{\mathrm{A} 18}+\mathrm{Asp}^{\mathrm{B} 3}$ showed higher RMSDs during the first $60 \mathrm{~ns}$ of the simulation relative to WT protein and similar type of deviations throughout the following $40 \mathrm{~ns}$ of RMSD trajectories. In turn, the simulation of mutants Asp ${ }^{\mathrm{B} 10}$, Gln ${ }^{\mathrm{B} 17}$, $\mathrm{Ser}^{\mathrm{A} 13}+\mathrm{Glu}^{\mathrm{B} 27}$ and $\mathrm{Ser}^{\mathrm{B} 2}+\mathrm{Asp}^{\mathrm{B} 10}$ produced less stable trajectories in comparison with WT insulin.
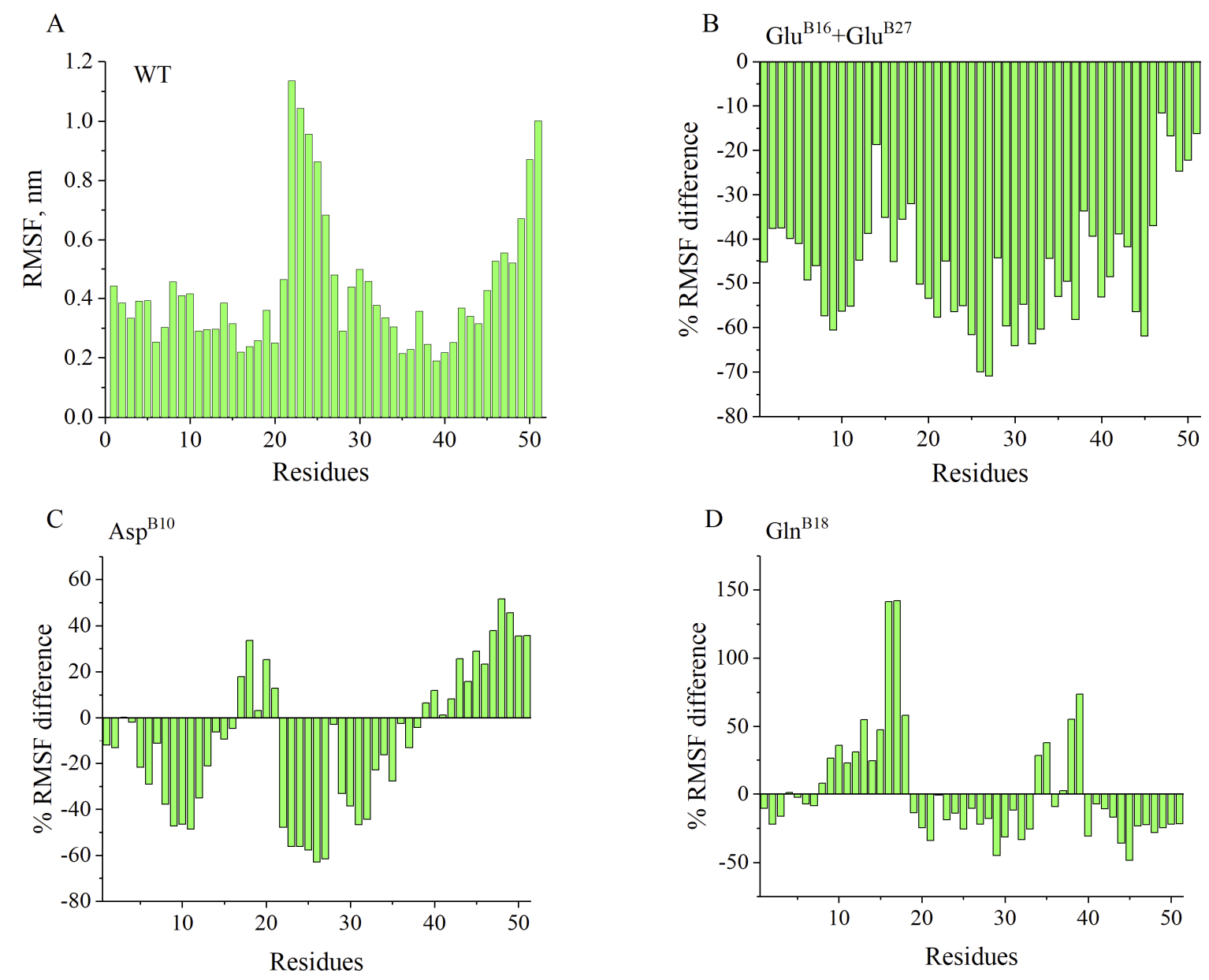

Figure 2. The root mean square fluctuations of the C-alpha atoms of WT insulin( A) and the relative changes in root-mean-square fluctuations for $\mathrm{Glu}^{\mathrm{B} 16}+\mathrm{Glu}^{\mathrm{B} 27}(\mathrm{~B}), \mathrm{Asp}^{\mathrm{B} 10}(\mathrm{C}), \mathrm{Gln}^{\mathrm{B} 18}(\mathrm{D})$ insulin mutants, calculated as $\left(\frac{R M S F_{m u t}}{R M S F_{W T}}-1\right) \cdot 100 \%$.

To determine how the mutations affect the dynamic behavior of amino acid residues, the RMSF values of the C-alpha atoms of WT insulin and mutants were calculated (Fig. 2). The RMSF values for the majority of the WT protein residues ranged from 0.2 to $0.5 \mathrm{~nm}$ during the simulation (Fig. 2.A). The only exception were the residues 22-26 (RMSFs vary from 0.68 to $1.14 \mathrm{~nm}$ ) representing the first five residues of the $\mathrm{N}$-terminal region of B-chain, and the residues 46-51 (RMSFs vary from 0.52 to $1.0 \mathrm{~nm}$ ), belonging to the end of the C-terminal of this chain. The analysis of the relative changes in RMSF revealed that both $\mathrm{N}$ - and C-terminal regions of B-chain in all mutants fluctuate stronger that in the WT insulin with the magnitude of this effect being dependent on the type of mutation (data not shown). More specifically, there are three main tendencies in the relative changes of RMSF, according to which all examined mutants can be divided into three groups. The representatives of the first group ( $\mathrm{Val}^{\mathrm{A} 10}, \mathrm{Ala}^{\mathrm{B} 17}, \mathrm{Asp}^{\mathrm{B} 28}, \mathrm{Ser}^{\mathrm{A} 13}+\mathrm{Glu}^{\mathrm{B} 27}, \mathrm{Glu}^{\mathrm{B} 1}+\mathrm{Glu}^{\mathrm{B} 27}$ and $\mathrm{Asp}^{\mathrm{B} 9}+\mathrm{Glu}^{\mathrm{B} 27}$ ) are characterized by strong fluctuations of similar amplitudes on both $\mathrm{N}$ - and C-terminal regions of B-chain. The second group contains $\mathrm{Gln}^{\mathrm{B} 18}, \mathrm{Glu}^{\mathrm{B} 27}$ and $\mathrm{Glu}^{\mathrm{A} 15}+\mathrm{Asp}^{\mathrm{A} 18}+\mathrm{Asp}^{\mathrm{B} 3}$ mutants which, like WT insulin, display significantly higher fluctuations in the N-terminal region in comparison with C-terminal part of B-chain. For all other mutants under study (the third group) the relative changes of RMSF values were opposite to those observed for the second 
group. The obtained results are in good agreement with the experimental evidence for the higher conformational flexibility of B-chain with respect to the rest of the protein $[29,31]$.

Notably, some mutants have significantly larger fluctuations in A-chain residues compared to the 7-22 sequence of the core of B-chain. Specifically, higher RMSFs were observed for $\mathrm{Val}^{\mathrm{A} 10}$ (1-5, 13-15 and 18-19 A-chain residues), Gln ${ }^{\mathrm{B} 18}$ (8-10 and 13-18 A-chain residues), $\mathrm{Asp}^{\mathrm{B} 25}$ (1-5, 10 and 12-15 A-chain residues), $\mathrm{Asp}^{\mathrm{B} 28}$ (1-5 and 12-15 A-chain residues), $\mathrm{Ser}^{\mathrm{A} 13}+\mathrm{Glu}^{\mathrm{B} 27}$ (1-5 and 11-14 A-chain residues), $\mathrm{Ser}^{\mathrm{B} 2}+\mathrm{Asp}^{\mathrm{B} 10}$ (1-4 and 14 A-chain residues), $\mathrm{Glu}^{\mathrm{A} 15}+\mathrm{Asp}^{\mathrm{A} 18}+\mathrm{Asp}^{\mathrm{B} 3}$ (8-10 A-chain residues). Remarkably, although the above results demonstrate the increase in RMSFs (in comparison with B-chain) for the polypeptide fragment consisting of 8-19 residues responsible for the stabilization of insulin fibrils [28,30], the mutations didn't significantly modify the conformation of this region, since the mutated and WT insulin showed nearly similar RMSFs for this sequence of residues.

It has been suggested previously that local unfolding of the B11-B17 fragment of insulin causes the increase in fibrillization rate [37]. However, as seen in Fig. 2 (panels B-D) the fluctuations of these residues were even smaller than those for WT protein. Nevertheless, the comparison of the relative changes in root-mean-square fluctuations of WT insulin and its mutants indicates the stabilizing effect of mutations $\mathrm{His}^{\mathrm{A} 8}, \mathrm{Val}^{\mathrm{A} 10}, \mathrm{Ala}^{\mathrm{B} 17}, \mathrm{Asp}^{\mathrm{B} 25}, \mathrm{Thr}^{\mathrm{B} 26}, \mathrm{Glu}^{\mathrm{B} 27}, \mathrm{Glu}^{\mathrm{A} 13}+\mathrm{Glu}^{\mathrm{B} 10}$, $\mathrm{Glu}^{\mathrm{B} 1}+\mathrm{Glu}^{\mathrm{B} 27}$ and $\mathrm{Glu}^{\mathrm{B} 16}+\mathrm{Glu}^{\mathrm{B} 27}$ on virtually all protein residues (the relative changes in root-mean-square fluctuations $\leq$ $74 \%$ ). Notably, the highest fluctuations were observed for the variant $\mathrm{Gln}^{\mathrm{B} 18}$ which is characterized by the increase of A16 and A17 RSMFs to 141\% compared to WT insulin. The analysis of the relative changes in the RMSF revealed that the region B20-B30 fluctuates stronger in the mutants $\mathrm{Glu}^{\mathrm{A} 15}+\mathrm{Asp}^{\mathrm{A} 18}+\mathrm{Asp}^{\mathrm{B} 3}(\sim 39 \%), \mathrm{Gln}^{\mathrm{B} 17}(\sim 67 \%), \mathrm{Asp}^{\mathrm{B} 10}(\sim 52 \%)$, $\mathrm{Ser}^{\mathrm{A} 13}+\mathrm{Glu}^{\mathrm{B} 27}(\sim 65 \%), \mathrm{Ser}^{\mathrm{B} 2}+\mathrm{Asp}^{\mathrm{B} 10}(\sim 66 \%)$ and $\mathrm{Gln}^{\mathrm{B} 18}(\sim 73 \%)$ than in the WT protein. The mutants Asp ${ }^{\mathrm{B} 28}$, $\mathrm{Ser}^{\mathrm{A} 13}+\mathrm{Glu}^{\mathrm{B} 27}, \mathrm{Gln}^{\mathrm{B} 18}$ have significantly larger fluctuations in the A8-A18 region, with RMSF difference ranging from $\sim 35 \%$ to $\sim 72 \%$. By considering the amount of residues fluctuating stronger than in the WT protein, along with the maximal positive and negative relative RMSF changes, we observed that the destabilizing impact of mutants on the protein dynamics increases in the following row: $\mathrm{Asp}^{\mathrm{B} 25}<\mathrm{Asp}^{\mathrm{B} 9}+\mathrm{Glu}^{\mathrm{B} 27}<\mathrm{Glu}^{\mathrm{A} 15}+\mathrm{Asp}^{\mathrm{A} 18}+\mathrm{Asp}^{\mathrm{B} 3}<\mathrm{Gln}^{\mathrm{B} 17}<\mathrm{Asp}^{\mathrm{B} 28}<\mathrm{Asp}^{\mathrm{B} 10}<$ $\mathrm{Ser}^{\mathrm{A} 13}+\mathrm{Glu}^{\mathrm{B} 27}<\mathrm{Ser}^{\mathrm{B} 2}+\mathrm{Asp}^{\mathrm{B} 10}<\mathrm{Gln}^{\mathrm{B} 18}$.

Fig. 3 represents the time-course evolution of the radius of gyration.
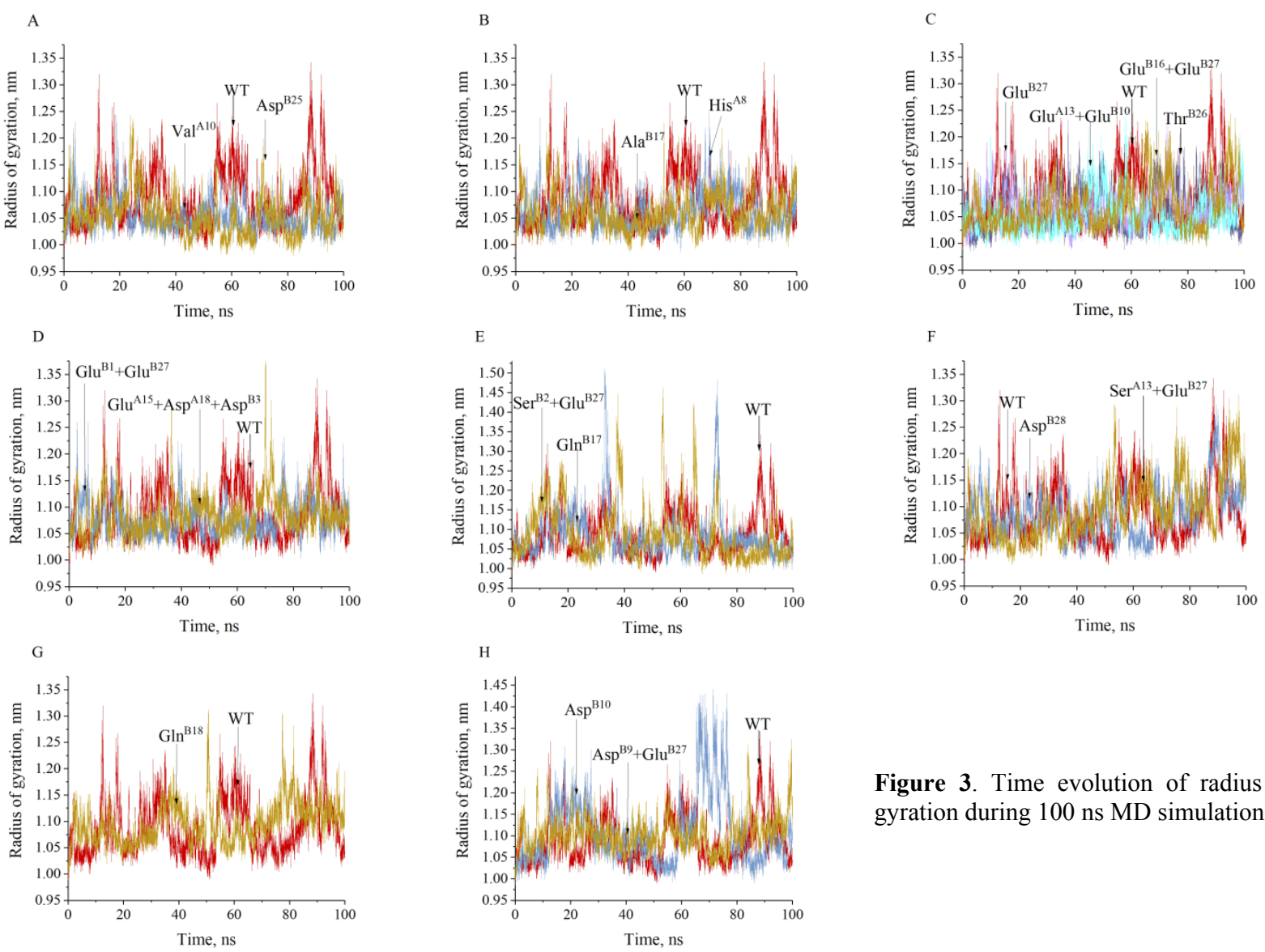

Figure 3. Time evolution of radius of gyration during $100 \mathrm{~ns}$ MD simulations.

The $\mathrm{Rg}$ value of the WT insulin rises from $\sim 1$ to $\sim 1.34 \mathrm{~nm}$. The approximation of the time dependence of the radius of gyration by the linear function showed that the slop of graph increases with time from $\sim 1.07 \mathrm{~nm}$ at the beginning of simulation to $\sim 1.1 \mathrm{~nm}$ at $100 \mathrm{~ns}$. Since the gyration radius correlates with the extent of protein unfolding, the approximation of the time evolution of the radius of gyration by the linear function allowed us to identify the three groups of mutants. The first group contains $\mathrm{Glu}^{\mathrm{A} 13}+\mathrm{Glu}^{\mathrm{B} 10}, \mathrm{Glu}^{\mathrm{B} 16}+\mathrm{Glu}^{\mathrm{B} 27}, \mathrm{Thr}^{\mathrm{B} 26}, \mathrm{Glu}^{\mathrm{B} 27}, \mathrm{His}^{\mathrm{A} 8}, \mathrm{Ala}^{\mathrm{B} 17}, \mathrm{Val}^{\mathrm{A} 10} \mathrm{and} \mathrm{Asp}^{\mathrm{B} 25}$ whose 
approximation lines are positioned below the approximation line of WT protein (Fig. 2.A-C). The second group includes $\mathrm{Glu}^{\mathrm{B} 1}+\mathrm{Glu}^{\mathrm{B} 27}, \mathrm{Glu}^{\mathrm{A} 15}+\mathrm{Asp}^{\mathrm{A} 18}+\mathrm{Asp}^{\mathrm{B} 3}, \mathrm{Ser}^{\mathrm{B} 2}+\mathrm{Asp}^{\mathrm{B} 10}, \mathrm{Gln}^{\mathrm{B} 17}, \mathrm{Asp}^{\mathrm{B} 28}, \mathrm{Ser}^{\mathrm{A} 13}+\mathrm{Glu}^{\mathrm{B} 27}$ and $\mathrm{Gln}^{\mathrm{B} 18}$, whose approximation lines are comparable with that for WT protein (Fig. 2.E-F), while $\mathrm{Gln}^{\mathrm{B} 1}$, $\mathrm{Asp}^{\mathrm{B} 10}$ and $\mathrm{Asp}^{\mathrm{B} 9}+\mathrm{Glu}^{\mathrm{B} 27}$ with approximation lines located significantly higher than that for WT insulin constitute the third group.

To assess the alterations in the environment of hydrophobic residues during the simulation, we concentrated on the relative changes in the solvent accessible surface area per residue SASA (Fig. 4). For WT insulin the SASA values do not exceed $1.8 \mathrm{~nm}$. We found that polar A5, A8, A21, B4, positively charged (B5, B10, B22, B29), negatively charged (A4, B13, B21), aromatic (A14, B1, B16, B25, B26) and three nonpolar residues (A10, B17 та B30) are highly accessible to the solvent during the simulation time (Fig. 4). Notably, the profiles of SASA per residue were similar for mutated and WT insulin, indicating that A14, B1, B21 and B29 residues are more accessible to water than the other residues in the protein sequence. Considering the number of residues whose SASA values are higher relative to WT protein, the examined mutants were found to follow the order: $\mathrm{Ala}^{\mathrm{B} 17}=\mathrm{Glu}^{\mathrm{B} 27}<\mathrm{Glu}^{\mathrm{B} 16}+\mathrm{Glu}^{\mathrm{B} 27}<\mathrm{Val}^{\mathrm{A} 10}, \mathrm{Glu}^{\mathrm{A} 13}+\mathrm{Glu}^{\mathrm{B} 10}=\mathrm{Thr}^{\mathrm{B} 26}=\mathrm{His}^{\mathrm{A} 8}$, $\mathrm{Gln}^{\mathrm{B} 18}<\mathrm{Glu}^{\mathrm{B} 1}+\mathrm{Glu}^{\mathrm{B} 27}=\mathrm{Asp}^{\mathrm{B} 25}<\mathrm{Gln}^{\mathrm{B} 17}<\mathrm{Ser}^{\mathrm{A} 13}+\mathrm{Glu}^{\mathrm{B} 27}<\mathrm{Asp}^{\mathrm{B} 28}, \mathrm{Ser}^{\mathrm{B} 2}+\mathrm{Asp}^{\mathrm{B} 10}=\mathrm{Glu}^{\mathrm{A} 15}+\mathrm{Asp}^{\mathrm{A} 18}+\mathrm{Asp}^{\mathrm{B} 3}<$ $\mathrm{Asp}^{\mathrm{B} 9}+\mathrm{Glu}^{\mathrm{B} 27}=\mathrm{Asp}^{\mathrm{B} 10}$.

A

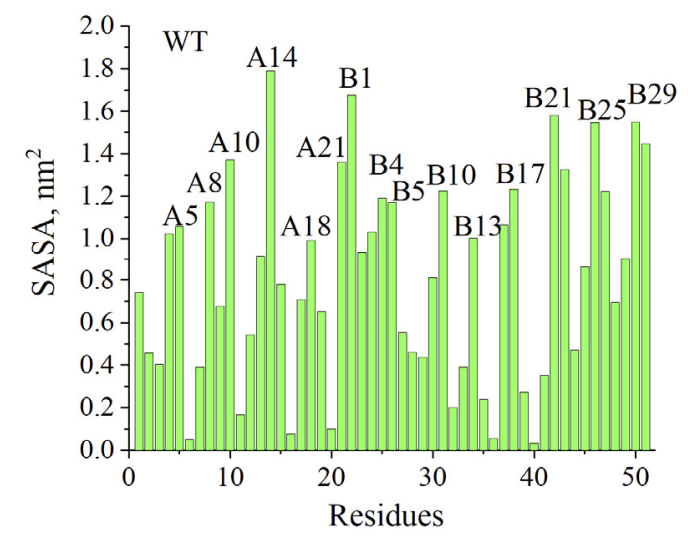

B

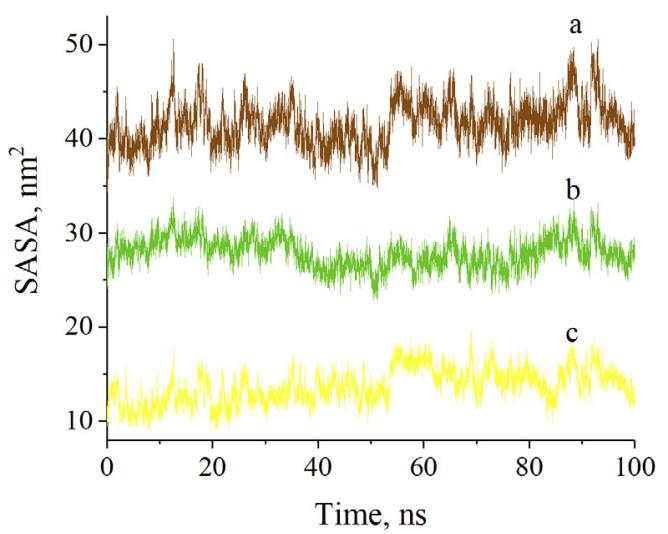

Figure 4. The solvent accessible surface area per residue (A) and time evolution of SASA (B) for whole protein (a), its hydrophobic (b) and hydrophilic (c) residues calculated for wild type insulin.

Notably, depending on the decrease or increase of SASA relative to WT protein, all residues can be divided into two groups. The first group includes the residues A4, A7, A17, A20, B1, B7, B9, B12, B13, B16-B22, B47 and B29, whose SASA is greater than that of WT insulin. In turn, the residues of the second group (A1-A3, A5, A6, A8-A14, A16, A19, A21, B2-B6, B8, B10, B11, B14, B15, B23-B25, B28, B30) are characterized by lower SASA values. Remarkably, the hydrophobic residues represent $\sim 32 \%$ and $\sim 63 \%$ of all residues in the first and second groups, respectively, being indicative of the decreased solvent accessibility of nonpolar and aromatic residues of mutants in comparison with WT protein.

To take a closer look on the impact of hydrophobic and hydrophilic residues on the solvent accessible surface area, the time evolution of SASA values was analyzed for: 1) all protein residues; 2) hydrophobic residues; and 3) hydrophilic residues (Fig. 4.B). The approximation of the time-course SASA evolution by the linear function for all protein residues and independently for hydrophobic and hydrophilic residues showed that:

1) The growth of the total SASA value with time is caused by the increase of both the hydrophobic and hydrophilic SASAs for $\mathrm{Asp}^{\mathrm{B} 10}, \mathrm{Ala}^{\mathrm{B} 17}, \mathrm{Gln}^{\mathrm{B} 18}, \mathrm{Thr}^{\mathrm{B} 26}, \mathrm{Asp}^{\mathrm{B} 28}, \mathrm{Glu}^{\mathrm{A} 13}+\mathrm{Glu}^{\mathrm{B} 10}, \mathrm{Ser}^{\mathrm{A} 13}+\mathrm{Glu}^{\mathrm{B} 27} \mathrm{Ta} \mathrm{Glu}^{\mathrm{B} 16}+\mathrm{Glu}^{\mathrm{B} 27}$;

2) The increase of the total SASA value with time for the wild type protein and the mutants $\mathrm{Glu}^{\mathrm{B} 27}$, $\mathrm{Glu}^{\mathrm{A} 15}+\mathrm{Asp}^{\mathrm{A} 18}+\mathrm{Asp}^{\mathrm{B} 3}, \mathrm{Asp}^{\mathrm{B} 9}+\mathrm{Glu}^{\mathrm{B} 27}$ results from the increase of the solvent accessibility of hydrophobic residues;

3) A slight increase of the total SASA for $\mathrm{His}^{\mathrm{A} 8}$ and $\mathrm{Glu}^{\mathrm{B} 1}+\mathrm{Glu}^{\mathrm{B} 27}$ reflects the increase of the solvent accessibility of hydrophilic residues;

4) The decrease of the total SASA with time observed for $\mathrm{Gln}^{\mathrm{B} 17}$, originates from the reduction of SASAs for hydrophilic residues;

5) The solvent accessibility of both hydrophobic and hydrophilic residues reduces for $\mathrm{Val}^{\mathrm{A} 10}, \mathrm{Asp}^{\mathrm{B} 25}$ and $\mathrm{Ser}^{\mathrm{B} 2}+\mathrm{Asp}^{\mathrm{B} 10}$

The above results indicate that the replacement of superficial nonpolar residues by hydrophilic ones increases the insulin stability in comparison with the wild type protein.

Next, to clarify the effect of mutations on the insulin unfolding pathway, we analyzed the time course of the changes in protein secondary structure through determining the percentage of residues adopting the $\alpha$-helix, $\beta$-sheet or 310 -helix conformations during the simulation (Table 1). It appeared that the content of $\alpha$-helices rises from $35 \%$ to $50 \%$ in the following raw: $\mathrm{Asp}^{\mathrm{B} 9}+\mathrm{Glu}^{\mathrm{B} 27}<\mathrm{Gln}^{\mathrm{B} 18}<\mathrm{Ser}^{\mathrm{A} 13}+\mathrm{Glu}^{\mathrm{B} 27}<\mathrm{Asp}^{\mathrm{B} 28}<\mathrm{Asp}^{\mathrm{B} 25}<\mathrm{Glu}^{\mathrm{B} 16}+\mathrm{Glu}^{\mathrm{B} 27}<\mathrm{Glu}^{\mathrm{B} 1}+\mathrm{Glu}^{\mathrm{B} 27}<$ $\mathrm{Val}^{\mathrm{A} 10}<\mathrm{Thr}^{\mathrm{B} 26}<\mathrm{Ala}^{\mathrm{B} 17}<\mathrm{His}^{\mathrm{A} 8}<\mathrm{Glu}^{\mathrm{B} 27}<\mathrm{Glu}^{\mathrm{A} 13}+\mathrm{Glu}^{\mathrm{B} 10}<\mathrm{WT}<\mathrm{Glu}^{\mathrm{A} 15}+\mathrm{Asp}^{\mathrm{A} 18}+\mathrm{Asp}^{\mathrm{B} 3}<\mathrm{Ser}^{\mathrm{B} 2}+\mathrm{Asp}^{\mathrm{B} 10}<$ 
$\mathrm{Asp}^{\mathrm{B} 10}<\mathrm{Gln}^{\mathrm{B} 17}$. Given that the native insulin contains $3 \alpha$-helices $(47 \%)$, the above results can be explained either by the destruction of $\alpha$-helices during the simulation or the appearance of the additional $\alpha$-helix conformations. In turn, we observed only small percentage of $\beta$-sheets (absent in the native conformation) increasing in the order: $\mathrm{Asp}^{\mathrm{B} 9}+\mathrm{Glu}^{\mathrm{B} 27}<$ $\mathrm{Glu}^{\mathrm{A} 15}<\mathrm{Asp}^{\mathrm{A} 18}+\mathrm{Asp}^{\mathrm{B} 3}<\mathrm{Val}^{\mathrm{A} 10}<\mathrm{WT}<\mathrm{Gln}^{\mathrm{B} 18}<\mathrm{Ser}^{\mathrm{B} 2}+\mathrm{Asp}^{\mathrm{B} 10}<\mathrm{Thr}^{\mathrm{B} 26}<\mathrm{Ala}^{\mathrm{B} 17}<\mathrm{Asp}^{\mathrm{B} 25}<\mathrm{Asp}^{\mathrm{B} 10}<\mathrm{His}^{\mathrm{A} 8}<\mathrm{Glu}^{\mathrm{B} 27}<$ $\mathrm{Glu}^{\mathrm{B} 16}+\mathrm{Glu}^{\mathrm{B} 27}<\mathrm{Ser}^{\mathrm{A} 13}+\mathrm{Glu}^{\mathrm{B} 27}<\mathrm{Asp}^{\mathrm{B} 28}<\mathrm{Glu}^{\mathrm{A} 13}+\mathrm{Glu}^{\mathrm{B} 10}<\mathrm{Gln}^{\mathrm{B} 17}<\mathrm{Glu}^{\mathrm{B} 1}+\mathrm{Glu}^{\mathrm{B} 2}$.

Table 1. The percentage of residues adopting $\alpha$-helix, $\beta$-sheet or 3 10-helix conformations during the simulation

\begin{tabular}{|c|c|c|c|}
\hline Protein & $\beta$-sheet & $\alpha$-helix & $\mathbf{3}_{10}$-helix \\
\hline $\mathrm{WT}$ & 0.04 & 46.0 & 3.1 \\
\hline $\mathrm{His}^{\mathrm{A} 8}$ & 0.18 & 45.0 & 1.7 \\
\hline $\mathrm{Val}^{\mathrm{A} 10}$ & 0.02 & 44.5 & 2.7 \\
\hline $\mathrm{Asp}^{\mathrm{B} 10}$ & 0.16 & 47.0 & 1.7 \\
\hline $\mathrm{G} \ln { }^{\mathrm{B} 17}$ & 1.73 & 50.0 & 1.2 \\
\hline $\mathrm{Ala}^{\mathrm{B} 17}$ & 0.08 & 44.9 & 2.4 \\
\hline $\mathrm{G} \ln { }^{\mathrm{B} 18}$ & 0.04 & 36.1 & 4.6 \\
\hline $\mathrm{Asp}^{\mathrm{B} 25}$ & 0.15 & 43.7 & 2.1 \\
\hline $\mathrm{Thr}^{\mathrm{B} 26}$ & 0.08 & 44.7 & 3.1 \\
\hline $\mathrm{Glu}^{\mathrm{B} 27}$ & 0.24 & 45.7 & 2.5 \\
\hline $\mathrm{Asp}^{\mathrm{B} 28}$ & 0.72 & 38.6 & 3.7 \\
\hline $\mathrm{Glu}^{\mathrm{A} 13}+\mathrm{Glu}^{\mathrm{B} 10}$ & 0.87 & 45.8 & 1.5 \\
\hline $\mathrm{Ser}^{\mathrm{A} 13}+\mathrm{Glu}^{\mathrm{B} 27}$ & 0.30 & 37.0 & 3.7 \\
\hline $\mathrm{Glu}^{\mathrm{B} 1}+\mathrm{Glu}^{\mathrm{B} 27}$ & 2.08 & 44.5 & 2.9 \\
\hline $\mathrm{Ser}^{\mathrm{B} 2}+\mathrm{Asp}^{\mathrm{B} 10}$ & 0.08 & 47.5 & 1.3 \\
\hline $\mathrm{Asp}^{\mathrm{B} 9}+\mathrm{Glu}^{\mathrm{B} 27}$ & 0 & 34.7 & 5.0 \\
\hline $\mathrm{Glu}^{\mathrm{B} 16}+\mathrm{Glu}^{\mathrm{B} 27}$ & 0.30 & 44.3 & 2.6 \\
\hline $\mathrm{Glu}^{\mathrm{A} 15}+\mathrm{Asp}^{\mathrm{A} 18}+\mathrm{Asp}^{\mathrm{B} 3}$ & 0 & 46.7 & 4.3 \\
\hline
\end{tabular}

To characterize the changes in the secondary structure of mutants during the simulation, we analyzed the time evolution of $\alpha$-helices (Fig. 6). The wild type insulin was characterized by the fluctuations of the $\alpha$-helices content at the level $\sim 42 \%$ (first $25 \mathrm{~ns}$ of simulation), followed by the substantial increase of the percentage of $\alpha$-helices till $\sim 60 \%$ during the next $15 \mathrm{~ns}$ period, after which a slight helicity decrease was observed until achievement of the initial level of fluctuations to the end of the simulation. The curve of the time evolution of $\alpha$-helices for $\mathrm{Glu}^{\mathrm{A} 15}+\mathrm{Asp}^{\mathrm{A} 18}+\mathrm{Asp}^{\mathrm{B} 3}$ was almost identical to that for WT protein. Moreover, the fluctuations of the $\alpha$-helices content from $\sim 33 \%$ till $\sim 51 \%$ was observed for $\mathrm{Glu}^{\mathrm{B} 1}+\mathrm{Glu}^{\mathrm{B} 27}$, $\mathrm{Glu}^{\mathrm{B} 16}+\mathrm{Glu}^{\mathrm{B} 27}, \mathrm{His}^{\mathrm{A} 8}, \mathrm{Val}^{\mathrm{A} 10}, \mathrm{Ala}^{\mathrm{B} 17}, \mathrm{Thr}^{\mathrm{B} 26}, \mathrm{Glu}^{\mathrm{B} 27}, \mathrm{Glu}^{\mathrm{A} 13}+\mathrm{Glu}^{\mathrm{B} 10}$, reflecting the stability of their secondary structure during the simulation.
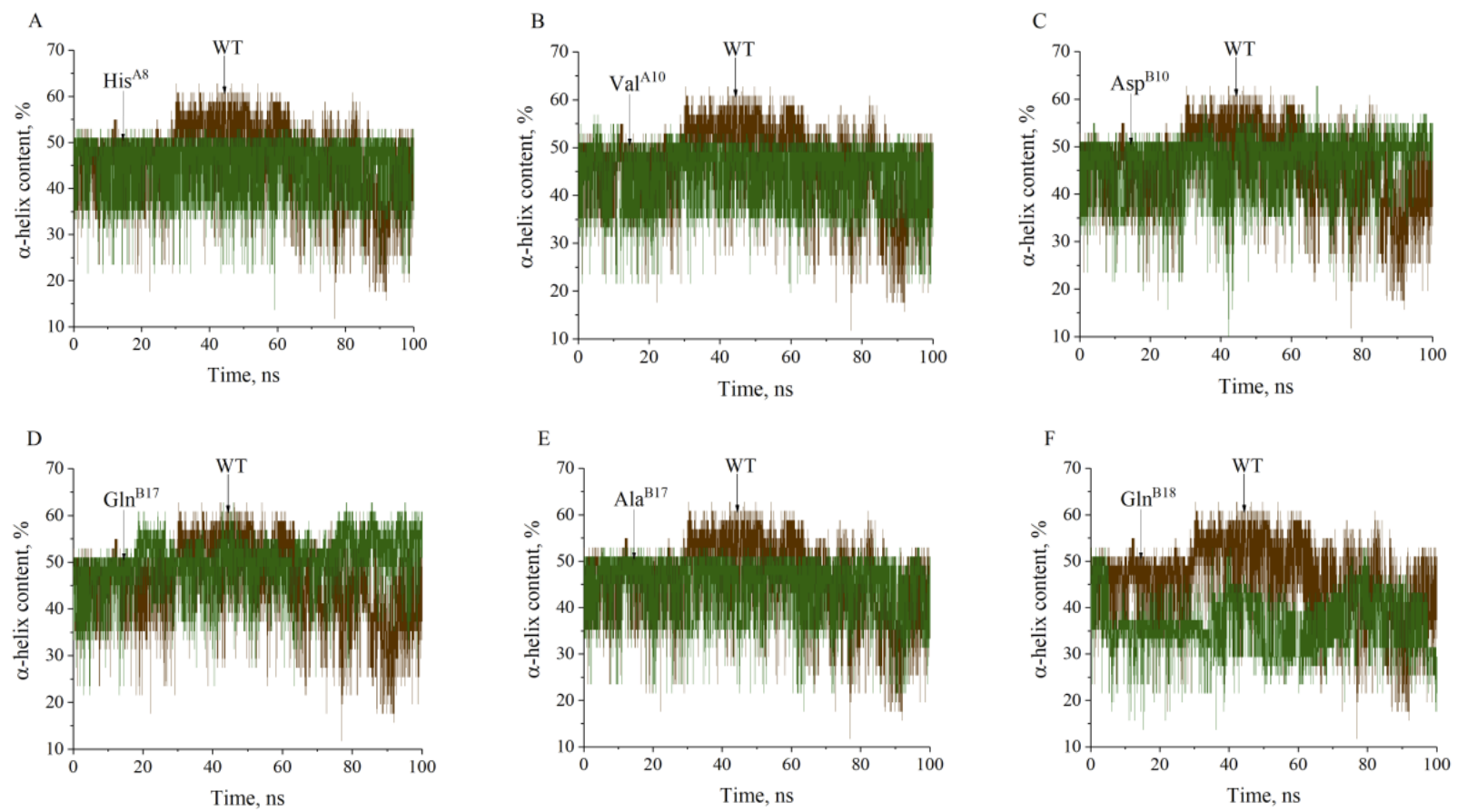

Figure 6. Time evolution of the $\alpha$-helices of wild type protein (brown) and mutants (green) (continued on next page) 

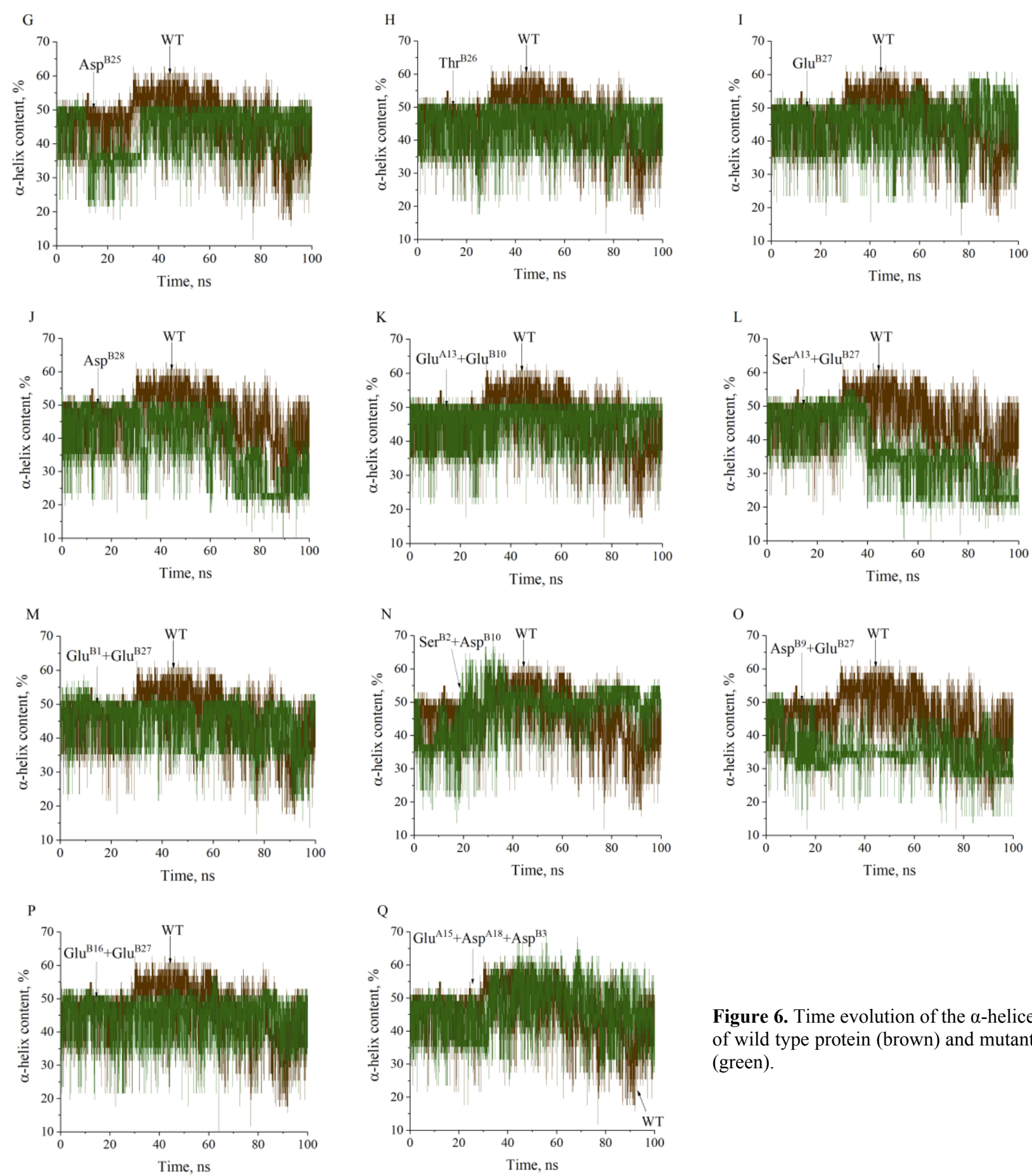

Figure 6. Time evolution of the $\alpha$-helices of wild type protein (brown) and mutants (green).

In turn, a slight increase of the percentage of $\alpha$-helices was observed for Asp ${ }^{\mathrm{B} 10}($ till $\sim 47-54 \%)$ and Gln ${ }^{\mathrm{B} 17}(\operatorname{till} \sim$ $46-61 \%$ ) during the simulation. Notably, the decrease of the $\alpha$-helices content with time was inherent to Asp ${ }^{\mathrm{B} 25}(\sim 25-$ $38 \%$ during the period 11-33 ns), $\operatorname{Asp}^{\mathrm{B} 28}$ ( $\sim 22-36 \%$ from the $\left.70 \mathrm{~ns}\right), \mathrm{Ser}^{\mathrm{A} 13}+\mathrm{Glu}^{\mathrm{B} 27}(\sim 22-36$ starting after $38 \mathrm{~ns})$, Gln ${ }^{\mathrm{B} 18}$ ( 29-46\% beginning from $5 \mathrm{~ns}$ ) and $\mathrm{Asp}^{\mathrm{B} 9}+\mathrm{Glu}^{\mathrm{B} 27}(\sim 28-44 \% 36$ starting after $7 \mathrm{~ns})$. The analysis of the secondary structure content evidenced a higher unfolding extent of AspB28, AspB9+GluB27, SerA13+GluB27, GlnB18 in comparison with the WT protein.

\section{CONCLUSIONS}

To summarize, the present study indicates that introduction of 10 point mutations $\left(\mathrm{His}^{\mathrm{A} 8}, \mathrm{Val}^{\mathrm{A} 10}, \mathrm{Asp}^{\mathrm{B} 10}, \mathrm{Gln}^{\mathrm{B} 17}\right.$, $\mathrm{Ala}^{\mathrm{B} 17}, \mathrm{Gln}^{\mathrm{B} 18}, \mathrm{Asp}^{\mathrm{B} 25}, \mathrm{Thr}^{\mathrm{B} 26}, \mathrm{Glu}^{\mathrm{B} 27}, \mathrm{Asp}^{\mathrm{B} 28}$ ), 6 double mutations $\left(\mathrm{Glu}^{\mathrm{A} 13}+\mathrm{Glu}^{\mathrm{B} 10}, \mathrm{Ser}^{\mathrm{A} 13}+\mathrm{Glu}^{\mathrm{B} 27}, \mathrm{Glu}^{\mathrm{B} 1}+\mathrm{Glu}^{\mathrm{B} 27}\right.$, $\left.\mathrm{Ser}^{\mathrm{B} 2}+\mathrm{Asp}^{\mathrm{B} 10}, \mathrm{Asp}^{\mathrm{B} 9}+\mathrm{Glu}^{\mathrm{B} 27}, \mathrm{Glu}^{\mathrm{B} 16}+\mathrm{Glu}^{\mathrm{B} 27}\right)$ and one triple mutation $\left(\mathrm{Glu}^{\mathrm{A} 15}+\mathrm{Asp}^{\mathrm{A} 18}+\mathrm{Asp}^{\mathrm{B} 3}\right)$ in the protein sequence has different impact on the structural and dynamical properties of the human insulin. The MD simulation results showed that depending on time evolution of integral characteristics such as the backbone root mean-square deviation, gyration radius, solvent accessible surface area, the root mean-square fluctuations and the secondary structure content, the examined 
mutants can be tentatively divided into three groups: 1) the mutants $\mathrm{His}^{\mathrm{A} 8}, \mathrm{Val}^{\mathrm{A} 10}, \mathrm{Ala}^{\mathrm{B} 17}, \mathrm{Asp}^{\mathrm{B} 25}, \mathrm{Thr}^{\mathrm{B} 26}, \mathrm{Glu}^{\mathrm{B} 27}$, $\mathrm{Glu}^{\mathrm{A} 13}+\mathrm{Glu}^{\mathrm{B} 10}, \mathrm{Glu}^{\mathrm{B} 1}+\mathrm{Glu}^{\mathrm{B} 27}$ and $\mathrm{Glu}^{\mathrm{B} 16}+\mathrm{Glu}^{\mathrm{B} 27}$, exerting a stabilizing effect on the protein structure in comparison with wild type insulin; 2) the mutants $\mathrm{Gln}^{\mathrm{B} 17}, \mathrm{Asp}^{\mathrm{B} 10}, \mathrm{Ser}^{\mathrm{B} 2}+\mathrm{Asp}^{\mathrm{B} 10}$ and $\mathrm{Glu}^{\mathrm{A} 15}+\mathrm{Asp}^{\mathrm{A} 18}+\mathrm{Asp}^{\mathrm{B} 3}$ that did not significantly affect the dynamical properties of human insulin having a minimal stabilizing impact; 3) the mutants $\mathrm{Asp}^{\mathrm{B} 28}, \mathrm{Asp}^{\mathrm{B} 9}+\mathrm{Glu}^{\mathrm{B} 27}$, $\mathrm{Ser}^{\mathrm{A} 13}+\mathrm{Glu}^{\mathrm{B} 27}$ and $\mathrm{Gln}^{\mathrm{B} 18}$ destabilizing protein structure. The analysis of the time dependencies of the secondary structure content highlights the influence of $\mathrm{Asp}^{\mathrm{B} 28}, \mathrm{Asp}^{\mathrm{B} 9}+\mathrm{Glu}^{\mathrm{B} 27}, \mathrm{Ser}^{\mathrm{A} 13}+\mathrm{Glu}^{\mathrm{B} 27}$ and $\mathrm{Gln}^{\mathrm{B} 18}$ on the insulin unfolding. Moreover, our MD results indicate that substitution of the nonpolar residues in the insulin structure by hydrophilic ones caused the increase in protein stability in comparison with wild type protein.

\section{ACKNOWLEDGEMENTS}

This work was supported by the Ministry of Education and Science of Ukraine (the Young Scientist projects № 0120U101064 "Novel nanomaterials based on the lyophilic self-assembled systems: theoretical prediction, experimental investigation and biomedical applications" and the project № 0119U002525 “Development of novel ultrasonic and fluorescence techniques for medical micro- and macrodiagnostics”).

\section{ORCID IDs}

\footnotetext{
Olga Zhytniakivska, https://orcid.org/0000-0002-2068-5823; Uliana Tarabara, https://orcid.org/0000-0002-7677-0779

(D) Valeriya Trusova, https://orcid.org/0000-0002-7087-071X; (D) Kateryna Vus, https://orcid.org/0000-0003-4738-4016

(Dalyna Gorbenko, https://orcid.org/0000-0002-0954-5053
}

\section{REFERENCES}

[1] Q. Hua, Protein Cell. 1, 537-551 (2010), https://doi.org/10.1007/s13238-010-0069-z.

[2] F. Hu, Diabetes Care. 34, 1249-1257 (2011), https://doi.org/10.2337/dc11-0442.

[3] M. Atkinson, G. Eisenbarth, and A. Michels, The. Lancet. 383, 69-82 (2014), https://doi.org/10.1016/S0140-6736(13)60591-7.

[4] M. Nakamura, Y. Misumi, T. Nomura, W. Oka, A. Isoguchi, K. Kanenawa, T. Masuda, T. Yamashita, Y. Inoue, Y. Ando, and M. Ueda, Diabetes. 68, 609-616 (2019), https://doi.org/10.2337/db18-0846.

[5] T Nagase, K. Iwaya, K. Kogure, T. Zako, Y. Misumi, M. Kikuchi, K. Matsumoto, M. Noritake, Y. Kawachi, M. Kobayashi, Y. Ando, and Y. Katsura, J. Diabetes Investig. 11, 1002-1005 (2020), https://doi.org/10.1111/jdi.13199.

[6] Z.B. Taraghdari, R. Imani, and F. Mohabatpour, Macromol. Biosci. 19, 1800458 (2019), https://doi.org/10.1002/mabi.201800458.

[7] M. Akbarian, Y. Ghasemi, V. Uversky, and R. Yousefi. Int. J. Pharm. 547, 450-468 (2018), https://doi.org/10.1016/j.ijpharm.2018.06.023.

[8] L. Nielsen, R. Khurana, A. Coats, S. Frokjaer, J. Brange, S. Vyas, V.N. Uversky, and A.L. Fink, Biochemistry. 40, 6036-6046 (2001), https://doi.org/10.1021/bi002555c.

[9] M. Groenning, S. Frokjaer, and B. Vestergaard, Curr. Protein. Pept. Sci. 10, 509-528 (2009), https://doi.org/10.2174/138920309789352038.

[10] F. Librizzi, and C. Rischel, Protein Sci. 14, 3129-3134 (2005), https://doi.org/10.1110/ps.051692305.

[11] A. Podesta, G. Tiana, P. Milani, and M. Manno. Biophys J. 90, 589-597 (2006), https://doi.org/10.1529/biophysj.105.068833.

[12] S. Grudzielanek, R. Jansen, and R. Winter, J. Mol. Biol. 351,879-894 (2005), https://doi.org/10.1016/j.jmb.2005.06.046.

[13] A. Noormägi, K. Valmsen, V Tõugu, and P. Palumaa, Protein J. 34, 398-403 (2015), https://doi.org/10.1007/s10930-015-9634-x.

[14] J. Brange, L. Andersen, E. Laursen, G. Meyn, and E. Rasmussen, J. Pharm. Sci. 86, 517-525 (1997), https://doi.org/10.1021/js960297s.

[15] M. Ziaunys, T. Sneideris, and V. Smirnovas, Phys. Chem. Chem. Phys. 20, 27638-276455 (2018), https://doi.org/10.1039/C8CP04838J.

[16] M. Muzaffar, and A. Ahmad, Plos ONE. 20, e27906 (2011), https://doi.org/10.1371/journal.pone.0027906.

[17] I. Bekard, and D. Dunstan, Biophys J. 97, 2521-2531 (2009), https://doi.org/10.1016/j.bpj.2009.07.064.

[18] M. Sorci, R. Grassucci, I. Hahn, J. Frank, and G. Belfort, Proteins. 77, 62-73 (2009), https://doi.org/10.1002/prot.22417.

[19] C.G. Frankær, P. Sønderby, M.B. Bang, R.V. Mateiu, M. Groenning, J. Bukrinski, and P. Harris, J. Struct. Biol. 199, 27-38 (2017), https://doi.org/10.1016/j.jsb.2017.05.006.

[20] A. Noormagi, J. Gavrilova, J. Smirnova, V. Tõugu, and P. Palumaa, Biochem. J. 430, 511-518 (2010), https://doi.org/10.1042/BJ20100627.

[21] J. Hansen, Biophys. Chem. 39, 107-110 (1991), https://doi.org/10.1016/0301-4622(91)85011-E.

[22] A. Ahmad, V. Uversky, D. Hong, and A. Fink, J. Biol. Chem. 280 42669-42675 (2005), https://doi.org/10.1074/jbc.M504298200.

[23] M. Akbarian, R. Yousefi, A.A. Moosavi-Movahedi, A. Ahmad, and V.N. Uversky, Biophys. J. 117, 1626-1641 (2019), https://doi.org/10.1016/j.bpj.2019.09.022.

[24] D.P. Hong, A. Ahmad, and A.L. Fink, Biochemistry. 45, 9342-9353 (2006), https://doi.org/10.1021/bi0604936.

[25] D.P. Hong, and A.L. Fink, Biochemistry, 44, 16701-16709 (2005), https://doi.org/10.1021/bi051658y.

[26] R. Huang, N. Maiti, N. Philips, P.R. Carey, and M.A. Weiss, Biochemistry. 45, 10278-10293 (2006), https://doi.org/10.1021/bi060879g.

[27] M.I. Ivanova, S.A. Sievers, M.R. Sawaya, J.S. Wall, and D. Eisenberg, PNAS, 106, 18990-18995 (2009), https://doi.org/10.1073/pnas.0910080106.

[28] X.Q. Hua, and M.A. Weiss, J. Biol. Chem. 279, 21449-21460 (2004), https://doi.org/10.1074/jbc.M314141200.

[29] M. Bouchard, J. Zurdo, E.J. Nettleton, C.M. Dobson, and C.V. Robinson, Protein. Sci. 9, 1960-1967 (2008), https://doi.org/10.1110/ps.9.10.1960.

[30] V. Babenko, and W. Dzwolak, FEBS Lett. 587, 625-630 (2013), https://doi.org/10.1016/j.febslet.2013.02.010.

[31] L. Nielsen, S. Frokjaer, J. Brange, V.N. Uversky, and A.L. Fink, Biochemistry, 40, 8397-8409 (2001), https://doi.org/10.1021/bi0105983.

[32] S.A. Lieblich, K.Y. Fang, J.K.B. Cahn, J. Rawson, J. LeBon, H.T. Ku, and D.A. Tirrell, J. Am. Chem. Soc. 139, 8384-8387 (2017), https://doi.org/10.1021/jacs.7b00794.

[33] J. Huang, and A. MacKerell, J. Comput. Chem. 34, 2135-2145 (2013), https://doi.org/10.1002/jcc.23354.

[34] S. Jo, J. Lim, J. Klauda, and W. Im, Biophys. J. 97, 50-58 (2009), https://doi.org/10.1016/j.bpj.2009.04.013.

[35] T. Darden, D. York, and L. Pedersen, J. Chem. Phys. 98, 10089-10092 (1993), https://doi.org/10.1063/1.464397.

[36] W. Humphrey, A. Dalke, and K. Schulten, J. Mol. Graph. 14, 33-38 (1996), https://doi.org/10.1016/0263-7855(96)00018-5.

[37] T.S. Choi, J.W. Lee, K.S. Jin, and H.I. Kim, Biophys. J. 107, 1939-1949 (2014), https://doi.org/10.1016/j.bpj.2009.04.013. 


\section{МОЛЕКУЛЯРНО-ДИНАМІЧНЕ ДОСЛІДЖЕННЯ МУТАНТІВ ІНСУЛІНУ}

О. Житняківська, У. Тарабара, В. Трусова, К. Вус, Г. Горбенко

Кафедра медичної фізики та біомедичних нанотехнологій, Харківський національний університет імені В.Н. Каразіна м. Свободи 4, Харків, 61022, Украӥна

Інсулін людини, невеликий гормон пептидної природи, що складається 3 А-ланцюга (21 залишок) та Б- ланцюга, які зв’язані між собою трьома дисульфідними містками, має важливе значення для контролю гіперглікемії при діабеті I типу. У даній роботі методом молекулярно-динамічного моделювання досліджено вплив 10 точкових мутацій $\left(\mathrm{His}^{\mathrm{A} 8}, \mathrm{Val}^{\mathrm{A} 10}, \mathrm{Asp}^{\mathrm{B} 10}, \mathrm{Gln}^{\mathrm{B} 17}\right.$, $\left.\mathrm{Ala}^{\mathrm{B} 17}, \mathrm{Gln}^{\mathrm{B} 18}, \mathrm{Asp}^{\mathrm{B} 25}, \mathrm{Thr}^{\mathrm{B} 26}, \mathrm{Glu}^{\mathrm{B} 27}, \mathrm{Asp}^{\mathrm{B} 28}\right), 6$ подвійних мутацій $\left(\mathrm{Glu}^{\mathrm{A} 13}+\mathrm{Glu}^{\mathrm{B} 10}, \mathrm{Ser}^{\mathrm{A} 13}+\mathrm{Glu}^{\mathrm{B} 27}, \mathrm{Glu}^{\mathrm{B} 1}+\mathrm{Glu}^{\mathrm{B} 27}, \mathrm{Ser}^{\mathrm{B} 2}+\mathrm{Asp}^{\mathrm{B} 10}\right.$, $\left.\mathrm{Asp}^{\mathrm{B} 9}+\mathrm{Glu}^{\mathrm{B} 27}, \mathrm{Glu}^{\mathrm{B} 16}+\mathrm{Glu}^{\mathrm{B} 27}\right)$ та однієї потрійної мутації $\left(\mathrm{Glu}^{\mathrm{A} 15}+\mathrm{Asp}^{\mathrm{A} 18}+\mathrm{Asp}^{\mathrm{B} 3}\right)$ на структуру та динаміку інсуліну людини. 3 використанням програмного пакету GROMACS (версія 5.1) і силового поля CHARMM36m, було проведено серію 100 нс молекулярно-динамічних (МД) симуляцій дикого типа інсуліну людини (WT) та його мутантів при температурі $500 \mathrm{~K}$. Результати МД моделювання були проаналізовані в термінах параметрів, що характеризують як глобальну так і локальну структуру білка, таких як середньоквадратичне відхилення остову ланцюга, радіус інерції, площа поверхні, доступна для розчинника, середньоквадратичні флуктуації та вміст вторинної структури. Результати молекулярно-динамічного моделювання продемонстрували, що в залежності від еволюції інтегральних характеристик, усі досліджені мутанти можна умовно розділити на три групи: 1) мутанти $\mathrm{His}^{\mathrm{A} 8}, \mathrm{Val}^{\mathrm{A} 10}, \mathrm{Ala}^{\mathrm{B} 17}, \mathrm{Asp}^{\mathrm{B} 25}, \mathrm{Thr}^{\mathrm{B} 26}, \mathrm{Glu}^{\mathrm{B} 27}, \mathrm{Glu}^{\mathrm{A} 13}+\mathrm{Glu}^{\mathrm{B} 10}, \mathrm{Glu}^{\mathrm{B} 1}+\mathrm{Glu}^{\mathrm{B} 27} \mathrm{Ta}^{\mathrm{B}}$ $\mathrm{Glu}^{\mathrm{B} 16}+\mathrm{Glu}^{\mathrm{B} 27}$, що мають стабілізуючий вплив на структуру білка у порівнянні з диким типом інсуліну; 2) мутанти $\mathrm{Gln}{ }^{\mathrm{B} 17}$, $\mathrm{Asp}^{\mathrm{B} 28}, \mathrm{Asp}^{\mathrm{B} 10}, \mathrm{Ser}^{\mathrm{B} 2}+\mathrm{Asp}^{\mathrm{B} 10}$ та Glu $\mathrm{Al}^{\mathrm{A} 5}+\mathrm{Asp}^{\mathrm{A} 18}+\mathrm{Asp}^{\mathrm{B} 3}$, які істотно не впливали на динаміку білка або мали незначний стабілізуючий вплив; 3) мутанти $\mathrm{Asp}^{\mathrm{B} 9}+\mathrm{Glu}^{\mathrm{B} 27}, \mathrm{Ser}^{\mathrm{A} 13}+\mathrm{Glu}^{\mathrm{B} 27}$ та $\mathrm{Gln}^{\mathrm{B} 18}$, що дестабілізували структуру білка. При аналізі еволюції вторинної структури отримані докази впливу мутацій $\mathrm{Asp}^{\mathrm{B} 28}, \mathrm{Asp}^{\mathrm{B} 9}+\mathrm{Glu}^{\mathrm{B} 27}, \mathrm{Ser}^{\mathrm{A} 13}+\mathrm{Glu}^{\mathrm{B} 27}$ та Gln ${ }^{\mathrm{B} 18}$ на ступінь розгортання інсуліну. Результати МД демонструють, що заміна неполярних залишків в структурі інсуліну на гідрофільні, підвищує стабільність білка порівняно з інсуліном дикого типу.

КЛЮЧОВІ СЛОВА: людський інсулін, мутанти, молекулярно-динамічне моделювання, амілоїд. 